\title{
USING THE WORLD EXPERIENCE OF DEVELOPED COUNTRIES IN THE FORMATION OF DIRECTIONS FOR IMPROVING THE PROCESS OF DEVELOPMENT AND IMPLEMENTATION OF GOVERNMENT TARGETED PROGRAMS FOR NATURAL ENVIRONMENTAL PROTECTION
}

\author{
Oksana Senyshyn', Marta Olikhovska²
}

\begin{abstract}
The scientific article deals with the directions of improvement of the process of development and implementation of state targeted programs for protecting the natural environment in Ukraine. In particular, state targeted programs of environmental protection in Ukraine are the subject of this research. Methodology. A set of scientific research methods is used to realize the goals and tasks defined in the scientific article. Namely, the comparative method was used to compare the foreign experience of developed countries in the field of state programming of environmental protection and its adaptation to the conditions of Ukraine; to compare indicators that determine the level of development and implementation of state target programs of environmental protection in Ukraine; economic and statistical method used to investigate the state and trends of the development of the state programming system in Ukraine, to identify the main problems and obstacles related to its functioning; graphic interpretation method made it possible to visualize the principal scheme of management of domestic state target programs of environmental protection; the method of theoretical analysis, systemic and analytical methods, method of generalization, methods of grouping contributed to the identification of the main directions of improvement of the processes of development and implementation of state targeted programs for the protection of the natural environment in Ukraine. Information and reference base of scientific research consists of laws and other legal regulations of Ukraine on environmental protection issues, international documents, analytical and statistical materials of the State Statistics Service of Ukraine, reports on the implementation of State target programs for 2010-2016, scientific works of domestic scientists, periodicals, results of the authors' personal observations. Practical implementation. The authors have summarized their research results on the possibility of using the schematic model of managing the state targeted environmental protection program in Ukraine for the aspects related to creation and functioning of the Coordination Council, led by the program manager. The above mentioned Coordination Council is an advisory (collegial) body that operates on a voluntary basis. It is also substantiated that for Ukraine worthy of attention is the experience of the European Union countries, which radically changed the system of state management of environmental protection, and revised the balance of competence of different levels of government, through systematic improvement and alignment of the mechanisms of environmental management with international legal, normative-methodical and institutional basis of ecological management and ecological safety. The scientific value of research results. In the form of directions for improving the process of development and implementation of state targeted programs for the protection of the natural environment in Ukraine, a set of key recommendations has been proposed for improving the efficiency of functioning of the system of domestic state programming for natural environment protection.
\end{abstract}

Key words: state target program of environmental protection, programming, efficiency, state ecological policy, mechanism of state target ecological program management.

JEL Classification: Q56, O13, H53

\footnotetext{
Corresponding author:

${ }^{1}$ Ivan Franko National University of Lviv, Ukraine.

E-mail: okssenyshyn@gmail.com

${ }^{2}$ Lviv Institute of Private Joint-Stock Company "Higher Educational Institution

"Interregional Academy of Personnel Management", Ukraine.

E-mail: antonyaklviv@bigmir.net
} 


\section{Introduction}

The current practice of state programming of environmental activities shows a low efficiency of state regulation in this area. This is primarily due to the imperfection of the economic, legal, political, social mechanisms of environmental activity, the low level of its implementation in the practice of management, the lack of scientific research in this area, neglecting domestic and foreign best practices.

The main feature of the effective implementation of the state targeted programs (STPs) of environmental protection in Ukraine is their even and proportional financing throughout the implementation period. It requires involving both, budgetary and extrabudgetary funds, under constant and comprehensive control at all stages.

The issues related to using the mechanism of state target programs and assessing their effectiveness in the economy of Ukraine were investigated in a number of to scientific researches, conducted namely by such economists as V. M. Heiets (2008), L. S. Hryniv (2010), B. M. Danylyshyna (2008), O. S. Zarzhytskyi (2012), L. H. Melnyk (2003), T. O. Moshchytska (2010), O. V. Faychuk (2015), L. M. Yakushenko (2015), L. D. Yatsenko (2015), and others. Many publications of foreign scholars have been devoted to the study of theoretical and methodological and applied aspects of state environmental policy, in particular, state programming, such us: C. Kolstad (1999), R. Macrory (2006), N. Stanley (2009), S. Wolf (2009) etc.

The purpose of the article is to identify the main directions for improving the process of development and implementation of state target programs of environmental protection in Ukraine through the prism of the elaborated recommendations aiming to strengthen the control over the implementation of state targeted economic programs of environmental direction.

\section{The main problems related to the implementation of state target programs for the protection of the natural environment in Ukraine}

As follows from the recent scientific researches, financing of state target ecological programs can be effective only in case if at least $80 \%$ of planned funds are allocated from the budget with their consequent optimization by the method of program-targeted planning. In turn, governmental financing of state target environmental programs in the range of $35-80 \%$ of the need may take place, as it generally leads to an improvement in the state of the environment and people's health. At the same time, if the share of the state financing is less than $35 \%$ of the total funds provided it is more likely to lead to misuse of public finances (Senyshyn, 2017).
In order to elaborate proposals for improving the process of developing these environmental protection programs, it is necessary to indicate a complex of systemic deficiencies in the implementation of state target ecological programs, namely:

1. Governmental stakeholders in spite of the requirements of Article 8 of the Law of Ukraine "On State Target Programs” (Verkhovna Rada Ukrainy, 2004):

$\checkmark$ do not conduct a proper control over the implementation of activities and tasks of programs;

$\checkmark$ practically do not participate in conducting an annual analysis of the state of implementation of programs;

$\checkmark$ do not provide active work towards involving nonbudgetary sources of funding, especially in conditions of budget funds cut down (Ministerstvo ekonomiky Ukrainy, 2016).

2. The state environmental protection programs have not become an active and effective tool for implementing the state environmental policy, which should provide a solution of the most important environmental problems, individual branches of the economy. They act as a "formal paper with a declaration of intention to do something" (Zarzhytskyi, 2012).

3. Within the framework of planning and using the state budget funds, the principles of prioritization of the problems' resolution are not fully respected. Financial resources are sprawled.

4. Estimated volumes of financial resources of programs, including the state budget, are often not consistent with the real possibilities of their financing.

5. In contradiction to the requirements of the paragraph 29 of the Procedure for the development and implementation of state target programs approved by the Resolution of the Cabinet of Ministers of Ukraine dated January 31, 2007 No. 106 (hereinafter - the Procedure), the programs do not include methods for evaluating the effectiveness of their implementation, with due consideration to the limiting regulation for the use of natural resources, and with the legal emission standards (i.e. maximum permissible emission, maximum allowable discharges, maximum permissible pollution level), which should be developed by the state requisition maker taking into account the specificity of the program and its final results (Verkhovna Rada Ukrainy, 1991).

6. There is no opportunity for public control (paragraph 50 of the Order).

7. State requisition makers often use a formal approach to meeting the requirements of the current legislation in the field of development and implementation of state target programs.

8. Unsatisfactory reporting by government stakeholders: non-compliance with deadlines, information is not provided in full and not provided by all executives.

9. The expenditures for the financing of state environmental protection programs are represented in the state budget with lack of transparency. 
According to the proposals of the Ministry of Economic Development and Trade of Ukraine, following the results of monitoring of the years 2015-2016 (Ministerstvo ekonomiky Ukrainy, 2016): the state stakeholders continue ignoring the necessity to comply with the provisions of the legislation in the field of development and implementation of the State targeted programs; has not been ensured elaboration of draft normative legal acts on amendments to the programs in terms of clarification of the results indicators, the amounts of financing program tasks and measures, the timing of their implementation, taking into account the actual amounts of funding and the results achieved; government stakeholders have not developed methods for assessing the effectiveness of the implementation of state target programs, taking into account their specifics and end results.

The strategic objectives set out in the "Basic Principles (Strategy) of the State Environmental Policy of Ukraine for the Period until 2020" should be the benchmark when prioritizing objectives of state programs of environmental protection, rational use of natural resources and ensuring environmental safety (Verkhovna Rada Ukrainy, 1995).

\section{Experience of developed countries in the field of state programming of environmental protection and its adaptation to the conditions of Ukraine}

The experience of developed countries shows that due to conducting research works in the sphere of environmental protection, it is possible to achieve significant savings in implementing environmental measures and significantly reduce the damage from pollution and depletion of environmental components (Avramenko, Kushch, 2016).

Our scientific research confirmed that the governments of the leading countries of the world pay great attention to the problems of programming of environmental protection and environmental safety not only at the interstate but also at the state and regional levels (Hrusheva, 2007). The approach used by the world's leading countries to address these problems is directly based on the understanding that they must be solved locally, where the economic and social life of society is concentrated.

From this point of view, it is worth to explore the experience of state programming in the field of natural environment protection in Japan, where a number of administrative measures are widely used, including (Kernychna, 2013): introduction of standards for production quality and the state of the environment; ecological expertise; concluding agreements between local authorities and enterprises on pollution control, etc. One of Japan's most effective measures for environmental protection programming is the application of the "polluter pays" principle. Also, the country is a leader in using the ecologically friendly technology approach to guaranteeing environmental safety through the development of science.

In the United States, as well as in Europe, priorities have changed in the fight against atmospheric pollution. The main programs are targeting the creation of environmentally friendly technologies, but not on the improvement of waste and polluting emissions treatment. The US Bill "On Water Resources" provides for the implementation of 16 environmental programs. Criminal liability is established for intentional discharge of polluted wastewaters into the natural reservoirs, which threaten the health and life of people. Having created the necessary economic mechanism, the Americans managed not only to stop further pollution of the natural environment but also to significantly improve its quality. In the United States, environmental protection targets are set by the Federal Agency for the Conservation of Nature, and then each state separately proposes concrete measures for their implementation, linking them with their industrial development plans (Avramenko, Kushch, 2016).

Since 1973, special conservation programs have been developed in Western Europe. In these programs, the concept of sustainable development has been commonly recognized, according to which environmental and economic objectives should be aligned in the dynamics. And at the level of the European Union, its member states have developed principles and general measures for legislative acts in the field of nature protection.

New by the content policy of preservation of the environment is implemented in the form of national programs, which provide for the interaction of public authorities, the private sector, science, financial institutions. In all countries, laws on the protection of the natural environment have been adopted, in which the functions of the state for environmental protection regulation are defined, as well as the rights and obligations of environmental users are identified. For example, among such laws should be mentioned the law "On National Environmental Policy" (1970) of the United States of America, the law "On Addressing Environmental Pollution" (1967) in Japan, the law "On Environmental Protection" (1969) in Sweden. Special legislation aimed at preventing and eliminating violations of the quality of individual components of the environment is being implemented. Also, the legislative system on environmental protection is based on numerous regulations issued by local authorities, which take into account the natural geographic and socioeconomic specifics of a particular region (Avramenko, Kushch, 2016).

In the 1970s in the United States, a provision was made for mandatory state ecological expertise in all areas of economic activity. The policy in the field of environmental protection and financing of 
environmental protection measures are based on the principle of quality standards of the state of the environment. It can be provided by a system of standards on the permissible levels of anthropogenic loading, on the composition of pollution, emissions, discharges, or by the system of taxation of enterprises that allow violations of established requirements of nature use. Both principles can be organically interconnected. An effective method of controlling emissions is the introduction by the US Environmental Protection Agency of "permits" on the maximum allowable amount of pollutants that can be emitted into the environment. This measure has enabled firms, whose pollutant emissions are lower than the limit set for them, to sell their rights to other firms.

The UK's environmental policy is based, first of all, on the qualitative characteristics of the environment. It is recognized that it is necessary to carry out an environmental assessment before planning and designing any construction, and in the future - periodic monitoring of the state of the environment should be applied. Regarding ecological planning and programming, the initial version of the environmental expertise is compared with other variants of estimates, which allows more optimal determination of the parameters of anthropogenic impact (Hrusheva, 2007).

In Hungary, the management of activities in the field of nature conservation is distributed among different ministries and departments. According to the Law "On the Protection of Atmospheric Air", in Bulgaria, only the use of technology that ensures the minimum and allowable emissions of harmful substances into the air is compulsory for enterprises.

The use and protection of the environment in Poland are regulated by the Constitution, laws, and other legislative acts of the state. The State Environmental Inspectorate monitors compliance with laws and regulations (Kernychna, 2013).

In foreign countries, numerous economic and regulatory instruments are used. They are quite effective and diverse. As a result, many of the economically developed countries of the world have accumulated considerable experience in using various economic methods and tools for regulating the process of development ecologically friendly entrepreneurship at the macro and macro levels of economic activity.

In France, the control of water protection is carried out on the basis of the law adopted in 1964. Under this law, six basin administrations operate in the country. In the United Kingdom, according to the Water Resources Act (1973), 10 regional water committees monitor the status of the quality of water. In the Netherlands, in accordance with the law on surface water pollution, industrial enterprises and municipalities are required to have a waste disposal license (Tunytsia, 2006).

In Germany and the other countries of the European Union, the strategy of ecologically oriented management and environmental entrepreneurship is developed and implemented as one of the important areas of environmental modernization. In addition, all German companies are required to pass an environmental audit. Most countries have adopted their national standards that regulate environmental audit. Thus, in June 1993, the main principles and provisions of environmental accounting in the EU were adopted, which came into force in April 1995. According to estimates of the "German Environmental Agency in the area of environmental professional training and advanced training of specialists" now professional environmental interests are grouped according to their priority for those who study, as follows: waste management; environmental law; water economy; soil protection; energy saving; environmental protection at enterprises; regional ecological planning and programming; ecological expertise; environmental policy, etc. (Salatiuk, 2013).

Foreign practice shows that active state regulation is the basis of the whole environmental protection system in economically developed countries. In these regulations, significant priorities are given to economic stimulation and support of entrepreneurship that is developing in the direction of developing ecologically friendly social production.

Thus, social, ecological and economic integration of Ukraine should necessarily take into account the foreign experience of the mechanisms of nature use regulation through systematic improvement and alignment with the international legal, normative-methodical and institutional basis of environmental management and environmental safety.

The experience of foreign countries in the field of environmental programming demonstrates their readiness to actively participate in solving global environmental problems. This put on the agenda the adoption by Ukraine of relevant laws on the implementation of environmental objectives in the national policy and its adaptation to the European ecological space, the harmonization of national environmental requirements, standards and restrictions with corresponding indicators of the leading countries of the world. In particular, the experience of the European Union countries would be extremely useful for Ukraine, since these countries have radically changed the system of state management of environmental protection, and revised the hierarchy of competences of the various levels of state authorities.

\section{Modelling the process of management of the state target program of environmental protection in Ukraine}

It is important to note that during the formation of state target environmental protection programs, it is necessary to use a model that would allow certain mobility of financial funds that is required to tenable 
equal allocation of financial resources in order to obtain the maximum net environmental protection result (Hryniv, 2016). Implementation of state target programs for the protection of the natural environment requires considerable funds and it is necessary to carefully approach their formation and involve all possible sources of their financing.

In order to determine the strategy of formation and coordination of work on implementation and resource provision of tasks and measures of state targeted programs for the protection of natural environment, a program coordinator is formed by the program's initiator, which is the consultative (advisory) collegiate body that operates on a voluntary basis. The principal scheme of government targeted environmental protection program is shown in Figure 1.

Summing up the above, it should be emphasized that the effective implementation of state target programs for the protection of the natural environment requires: - improvement of the legal and regulatory framework for the process of their formation and implementation;

- developing appropriate methods for assessing the effectiveness of implementation for each target program, taking into account their specifics and end results;

- formation of state, regional, and local environmental funds for state target programs for the protection of the natural environment in order to accumulate and use of financial resources in an optimal way;

- creation of an information support centre of state target programs for the protection of the natural environment; - clearly defined and specially authorized bodies of management and control over state target programs within the framework of the program implementation.

In addition to the main controlling functions, the management bodies of state target programs for the protection of the natural environment must perform the functions related to:

- development and implementation of measures to mobilize financial, credit, material, and other types of resources for the implementation of tasks and activities envisaged by the program;

- creation of structural subdivisions and mechanisms for the development and implementation of the program;

- preparation of tasks and measures for the program implementation, assessing their effectiveness and determination of the cost of their implementation;

- management of scientific and informational services to support state target programs for the protection of the natural environment;

- organization of conducting procedures of ecological expertise, independent ecological audit at all stages of implementation of program tasks and measures;

- coordination of state target programs for the protection of the natural environment with programs of socio-economic development of the state and regions.

Therefore, the implementation and dissemination of the use of state target programs for the protection of the natural environment in the system of state regulation of environmental protection, rational use of natural resources and ensuring environmental safety will be effective due to their peculiarities. The most important of them, in our opinion, are:

- identification and orientation of all stages of management activity to achieve a clearly specified program goal; the goal should be specified in the relevant qualitative and quantitative indicators rather than in general, such as "improve", "increase", "enhance", etc.; - establishment from the beginning to the completion of the program implementation certain responsibilities



Figure 1. Principal scheme of management of state target programs for the protection of natural environment Source: compiled by the author 
of the target organizational units for the effectiveness of measures and tasks that are carried out both during the period of the program execution and during the process of resource provision;

- identification of all types of resources required for the implementation of program tasks and activities with their ranking according to the priority level;

- conjunction and coordinating the activities of various sectoral and territorial branches of management, in particular via the Program Coordinating Council;

- ensuring the consolidation of inter-sectoral interests

in solving territorial problems;

- concentration on the results to be obtained;

- a clear idea of the result increases the viability of attracting all kinds of resources.

\section{Recommendations for improving the efficiency of functioning of the system of domestic state programming for the protection of natural environment}

Therefore, in our opinion, the consideration of the following proposals will contribute to the improvement of the process of development of state targeted programs for the protection of the natural environment in Ukraine:

1. Promotion of innovation activity and research work in the field of monitoring the state of the environment, including:

- providing sufficient state support to research programs related to assessing the natural resource potential of Ukraine, developing and implementing a system of indicators for balanced development and spatial planning methods, the impact of environmental factors on the health of the population, as well as demographic trends; - conducting fundamental research on the formation of a new ideology of the life of Ukrainian society, aimed at the environmentally friendly economy, production, consumption, politics, education;

- investigating the ability of natural ecosystems to withstand anthropogenic burden;

- economic evaluation of the cost of natural resources; - promotion of scientific research in the field of effective teaching methods, tools for assessing the balance of development, the formation of lifestyle, attitudes and values.

2. Increasing public involvement in the development of state environmental protection projects.

3. Transparent information provision and access to reports on the implementation of state programs in the field of environmental protection.

4. Establishment of stable bilateral communication and cooperation between the developer of state environmental protection programs and the public environmental organizations and active population.

5 . The initiator of the program should ensure constant awareness of the population on the solution of local and national environmental problems and the process of transition to a balanced development with the active involvement of the media.

6. Improving the efficiency of management and professionalism of the executors of state programs in the field of environmental protection, including:

- ensuring the proper training and qualification improvement for persons authorized to perform public functions on balanced development, in particular balanced development planning;

- ensuring transparent decision-making on the use of natural resources, the implementation of investment projects that affect the quality of life of people, with the involvement of interested persons during their public discussions;

- compulsory following the legal procedures for decisionmaking in the field of environmental protection;

- introduction of clear mechanisms of reporting on the results to citizens at all levels;

- promoting a more complete integration at the vertical level between local and state authorities in the process of decision-making.

It is also necessary to change the approach to strategic planning in developing state environmental protection programs, based on the following:

$\checkmark$ the whole society, not just the state, is responsible for the environmental conditions;

$\checkmark$ not a fixed plan should be developed, but a system that can be continuously improved;

$\checkmark$ goals are determined based on an integral and complex approach;

$\checkmark$ decisions are made transparently;

$\checkmark$ continuous analysis of the results in order to improve environmental management.

\section{Development of a schematic model for the effective implementation of the state target program for the protection of the natural environment in Ukraine}

State target programs of environmental protection, rational use of nature (hereinafter - STEP) is an integrative environmental policy instrument, as well as the most effective and consistent with the principle of state regulation. Its successful application enables the most effective addressing of a set of complex problems associated with the environmental issues in Ukraine.

On the basis of our research, we elaborated proposals aimed at improving the development of state targeted environmental protection programs in Ukraine. We believe that the model for the effective implementation of the state target program for the protection of the natural environment should look like this (Figure 2).

According to the list of state target programs that were implemented within the framework of budget programs in 2015, there were 6 environmental programs against 18 in 2010 (Ministerstvo ekonomiky Ukrainy, 2016).

During 2014-2015, there were positive trends regarding the improvement of the management of the STEP: 


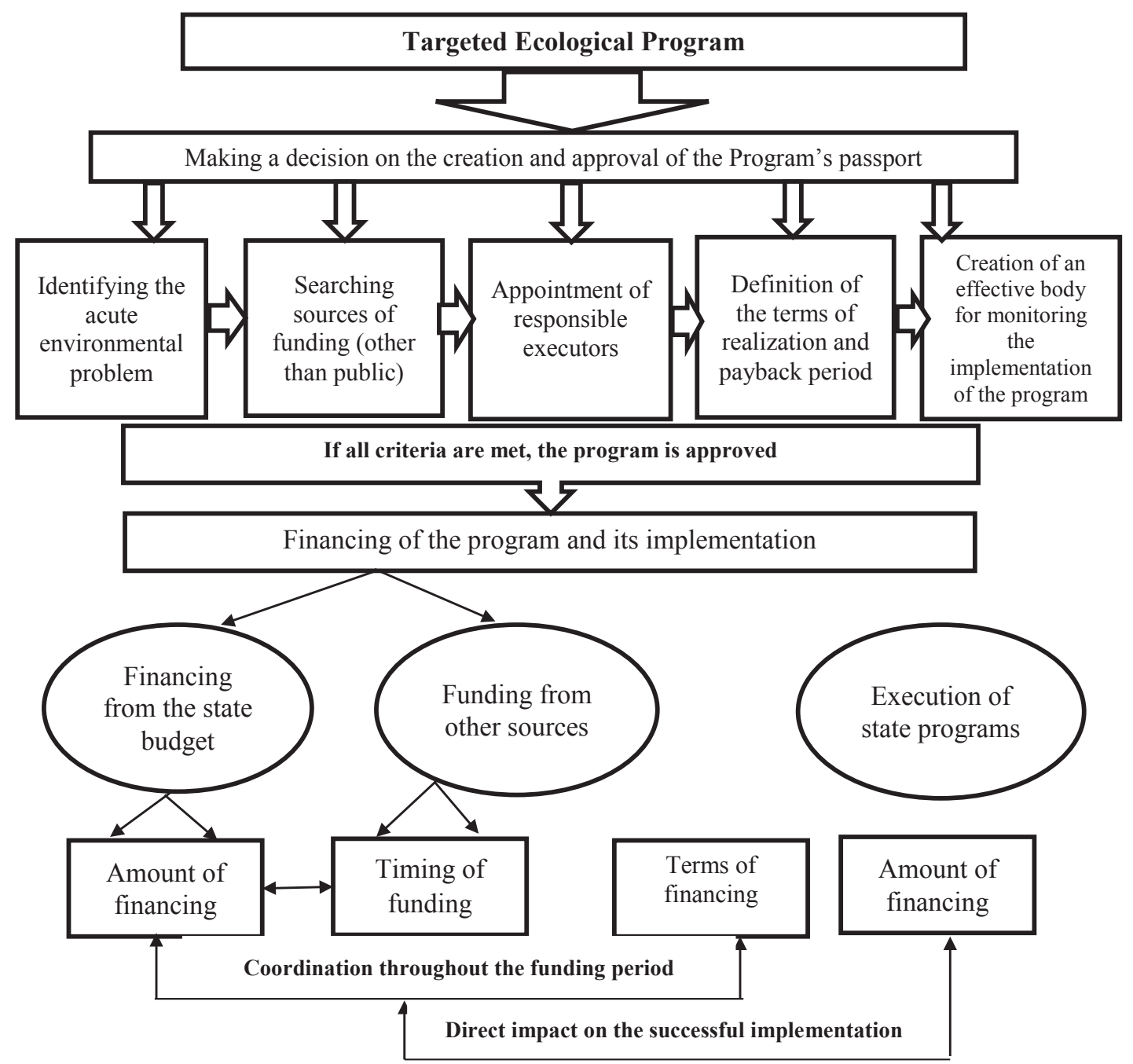

Figure 2. A descriptive model of effective implementation of the state the target program of environmental protection Source: compiled by the author

- the share of financing is gradually increasing, for example in 2015, the National Target Program for the development of the water sector and the environmental rehabilitation of the Dnipro river basin for the period up to 2021 was financed by $89.4 \%$; the State Target Program "Forests of Ukraine" for the period of 2010-2015 has been financed by 305.7\% (Verkhovna Rada Ukrainy, 2012; Kabinet Ministriv Ukrainy, 2009); - certain efforts are made to systematize and integrate programs for a more comprehensive solution to the problems of environmental protection and reproduction. The questions of optimization of state target programs and improving their operational management are considered in the Order of the Cabinet of Ministers of Ukraine dated March 23, 2011, No. 223-p, and the Resolution of the Verkhovna Rada of Ukraine "On Main Directions of Budget Policy for 2012" dated May 13, 2011, No. 3358-IV;

- the previous experience of programs' realization is taken into account: the miscalculations of the implementation of the Program of integrated flood protection in the basin of the Tysa River in the Transcarpathian region for 2002-2006 and the forecast by 2015 are taken into account in the development of the National Target Program for the Development of Water Management and Ecological Improvement of the Dnipro River Basin on the period until 2021 and the National Target Program "Drinking Water of Ukraine" for 2011-2020 (Verkhovna Rada Ukrainy, 2012, Verkhovna Rada Ukrainy, 2011).

\section{Conclusions and recommendations}

However, an analysis of the implementation of environmental target programs in Ukraine shows that there are significant miscalculations when applying them as an instrument of environmental policy.

1. The lack of financing of state target programs leads to the dispersal of budget funds and a significant reduction in efficiency. According to the reports of the Ministry 
of Ecology and Natural Resources of Ukraine, the state target environmental program for environmental monitoring (2008-2012) in 2010 was actually financed only by $9.2 \%$ of the planned annual amount.

2 . There are a lot of unresolved fundamental problems of identifying priorities for the formation of state programs, and no effective mechanism for selecting problems. The programs' measures are orientated to achieve the goal of overcoming the consequences, rather than the implementation of adequate preventive measures.

3. Lack of linking the financing of state target programs with the capacity of the state budget during the whole term of the program implementation. "The National Program for the Development of the Ukrainian Mineral Resources Base for the period up to 2030" in 2012 had an actual amount of financing of $52 \%$ of the planned amount. It was caused by lower incomes to the state budget from the fees for geological exploration work carried out by Naftogaz, which is allowed to postpone its tax liabilities.

4. The low level of programmatic and interprogrammatic coherence on the background of a large number of areas and a significant number of state target programs leads to duplication of tasks and activities of state target programs, which creates the possibility of financing the same activities from the budget funds under various programs. This, in turn, requires an urgent review of government targeted programs in order to exclude duplicate activities. For example, the National Program "Drinking Water of Ukraine for 2011-2020" contains some of the measures having been already announced in the National Program for the Ecological Recovery of the Dnieper and improvement of the quality of drinking water.

5. The lack of proper monitoring and control over the implementation of state target programs hinders properly conduct and adjust the implementation of the STEP. This impedes the establishment of reliable control over execution by both the responsible manager of funds and the Ministry of Finance and the State Treasury, complicates the analysis of cost-effectiveness and does not add transparency to budget flows. Given a large number of executives of the state program that belong to different executive structures and the need for wider involvement of extrabudgetary funds to finance programs, there is a need to create a coordinating structure at the level of the Cabinet of Ministers of Ukraine.

Given the complex nature of the STEP, in order to increase their efficiency and effectiveness, it is necessary not only to improve development standards, approval procedures and implementation mechanisms but also radically revise the system of environmental target programs in Ukraine, which has already been developed in order to unify and optimize it. Taking into account that the majority of the STEP is implemented over a sufficiently long time (more than five years), and the state of their implementation due to the abovementioned shortcomings is incomplete, ineffective and non-systematic, a careful revision of existing programs is a priority task. It is also necessary to assess the effectiveness of the implementation and expediency of continuing the implementation of existing programs, on the one hand, on the other hand - to build a sophisticated system for managing the formation and implementation of new integrated programs.

In order to increase the efficiency of the state programing of environmental protection, it is necessary to:

- improve the regulation of the mechanisms and procedures of the institution of state target programs. For this purpose, the Government of Ukraine should improve the procedure for the development and implementation of programs, which would regulate: strengthening control over the implementation of state target programs by clarifying the functions of the state customer-coordinator in relation to its responsibility for the preparation and implementation and increasing requirements for state customers regarding the financing of the envisaged measures, the issue of attracting reliable and predictable sources of extrabudgetary funding to ensure a reduction in the share of budget financing and opportunities manoeuvring in case of underfunding of state target programs at the expense of the state budget; - develop and legislatively establish a mechanism for the introduction of expert controlling over the implementation of state target programs, targeted and effective use of funds to identify and remedy shortcomings in the system of state target programs;

- resolve the issue of codification of state target programs within the framework of the Budget Classification to establish operational monitoring of financing of state targeted programs by the Ministry of Finance and the State Treasury and to ensure openness and transparency of procedures for the allocation and directing of budget funds to finance the activities of the STEP;

- optimize the structure of the STEP by excluding from their list those programs, which do not correspond to the development priorities, which will allow to concentrate funds on solving priority tasks and to match the need for financing programs with real budget possibilities and to ensure full financing of programs within certain time limits;

- introduce a scientifically based methodology for assessing the effectiveness of the STEP, with due consideration of the limitations on the use of natural resources, and with the emission standards (including maximum permissible emission, maximum allowable discharges, maximum permissible pollution level), to ensure methodological and organizational unity in the process of conducting annual audits on the implementation of targeted programs. This methodology should combine the formalized calculation procedure and expert assessments; 
In order to strengthen control over the implementation of the STEP, it is necessary:

1. To clarify the functions of the state initiatorcoordinator regarding his responsibility for the preparation and implementation of the STEPs, their financing, coordination of activities of state initiators, reporting on the progress of the programs implementation and the introduction of personal responsibility for the implementation of the STEPs, namely, the final results and the purposeful and efficient use of funds;

2. To oblige the initiator before the beginning of the implementation of the STEP to approve and submit to the Ministry of Economic Development and Trade of Ukraine the provisions on the management of the implementation of the STEP, which will determine:

- the procedure for forming an organizational and financial plan for the implementation of the state target program;

- mechanisms for adjusting program activities and their resource support during the implementation of the state target program;

- procedure for ensuring the publicity of monitoring of the implementation of program activities;

3. To increase the requirements to the state initiators regarding the financing of the STEP activities at the expense of extrabudgetary sources (other sources of funding);

4. To develop a mechanism of compensation in case of under-financing programs at the expense of state budget funds from extrabudgetary sources;

5 . To increase the requirements for annual reports from state initiators on the progress of the implementation of the STEP;

6. To work out the mechanism of expert checks on the progress of the implementation of the STEP, targeted and effective use of funds to identify shortcomings in the system of state target programs and develop measures for their elimination.

For successful implementation of the state target programs, it is expedient to use a new system in the framework of modern management - controlling, which, as according to the experience of the developed countries, enables coordinating and integrating efforts at a higher professional level, as well as independent environmental audit at all stages of the implementation of the program tasks and activities. Using a controlling mechanism and environmental audit will increase the effectiveness of program implementation and the level of reaching the program objectives.

Solving the problem of transforming the system of environmental target programs into an effective tool for implementing medium and long-term state policy is a complex task. To solve this issue, it is required to join efforts of central and local executive authorities, to introduce interconnected and comprehensive changes in the budget sphere, as well as in investment, industry and other types of national policy and their legislative provision.

Consequently, the existing mechanism of state programming in the ecological sphere in Ukraine can be classified as one of the "soft" type, which mainly aims at combating negative environmental consequences, and not with the causes of environmental destructive influences. For its improvement on the path to international integration into the world community, it is advisable to draw attention to the experience of leading countries in this area, especially the EU member states. A further profound study of the practice of international environmental management is needed in order to apply the integrated mechanism of state environmental protection management by introducing the latest tools, levers, methods in this area of public administration.

\section{References:}

Avramenko, N.L., Kushch, M. O. (2016). Dosvid YeSvsferi ekonomichnoho stymuliuvannia do okhorony navkolyshnoho pryrodnoho seredovyshcha [EU experience in the field of economic stimulation of environmental protection]. Retrieved from: http://molodyvcheny.in.ua/files/journal/2016/12/186.pdf (accessed 30 September 2018)

Danylyshyn, B. M. (2008). Naukovi narysy z ekonomiky pryrodokorystuvannia [Scientific essays on economy of the use of natural resources]. Kyiv: RVPS Ukrainy NAN Ukrainy. (in Ukraine)

Faychuk, O. V., Faychuk, O. M., Voytsekhivska, V. V. (2015). Efektyvne finansuvannia derzhavnykh tsilovykh ekolohichnykh prohram [Effective financing of state targeted ecological programs]. Economist, 7, 31-33.

Heiets, V. M. (2008). Derzhavni tsilovi prohramy ta uporiadkuvannia prohramnoho protsesu v biudzhetnii sferi [State targeted programs and streamlining the program process in the budget sphere]. Kyiv: Naukova Dumka. (in Ukraine)

Hrusheva, T. I. (2007). Zarubizhnyi dosvid ta mizhnarodni aspekty upravlinnia pryrodokorystuvanniam [Foreign experience and international aspects of environmental management]. Menedzher, 4(42), 32-38.

Hryniv, L. S. (2016). Fizychna ekonomiia: novi modeli staloho rozvytku [Physical economy: new models of sustainable development]. Lviv: Liha-pres. (in Ukraine)

Hryniv, L. S. (2010). Rehionalni tsilovi prohramy [Regional targeted programs]. Lviv: Lvivskyi natsionalnyi universytet imeni Ivana Franka. (in Ukraine)

Kernychna, A. Ye. (2013). Dosvid zarubizhnykh krain shchodo vdoskonalennia mekhanizmiv derzhavnoho upravlinnia $\mathrm{v}$ ekolohichnii sferi $\mathrm{u}$ konteksti yevrointehratsii [Experience of foreign countries in improving the mechanisms of public administration in the environmental sphere in the context of European integration]. Retrieved from: http://www.investplan.com.ua/pdf/24_2013/36.pdf (accessed 1 October 2018) 
Kolstad, Charles, D. (1999). Environmental Economics. Oxford: Oxford University Press, Inc. (in English) Lisovyi Kodeks No. 3852-XII of January 21 (1994). [Forest Code]. (Verkhovna Rada Ukrainy). Ofitsiinyi sait Verkhovnoi Rady Ukrainy. Retrieved from: http://zakon4.rada.gov.ua/laws/show/3852-12 (accessed 15 December 2017)

Macrory, R. (2006). Reflections on 30 years of Environmental Law: a high level of protection? Europe Law Publishing. (in English)

Melnyk, L. H. (2003). Ekolohichna ekonomika [Ecological economy]. Sumy: Universytetska knyha. (in Ukraine) Moshchytska, T. O. (2010). Derzhavni tsilovi prohramy yak diievyi instrument stymuliuvannia rozvytku ekonomiky [State targeted programs as an effective tool for stimulation of economic development]. Problemy ekonomiky, 3, 28-33. Postanova pro derzhavnu tsilovu prohramu Lisy Ukrainy na 2010-2015 rr. No. 977 of September 16 (2009). [Resolution on the State Targeted Program "Forests of Ukraine" for 2010-2015]. Ofitsiinyi sait Kabinetu Ministriv Ukrainy. Retrieved from: http://zakon2.rada.gov.ua/laws/show/977-2009-\%D0\%BF (accessed 28 November 2017)

Salatiuk, N. M. (2013). Zarubizhnyi dosvid rehuliuvannia pryrodokorystuvannia ta okhorony navkolyshnoho seredovyshcha [Foreign experience in the regulation of nature and environmental protection]. Retrieved from: http://dspace.nuft.edu.ua/jspui/bitstream/123456789/2486/1/333.pdf (accessed 2 October 2018)

Senyshyn, O., Chopko, N., Zhuk, I. (2017). Integral estimate of the effectiveness of performance of indices of the state targeted programs for protection of natural environment in Ukraine. Baltic Journal of Economic Studies, 3(5), 391-399. doi: 10.30525/2256-0742/2017-3-5-391-399

Stan vykonannia derzhavnykh tsilovykh prohram u 2015 rotsi (2016). [State of implementation of state targeted programs in 2015]. Ofitsiinyi sait Ministerstva ekonomiky Ukrainy. Retrieved from: https://issuu.com/ mineconomdev/docs/ (accessed 07 December 2017)

Tunytsia, T. Yu. (2006). Zbalansovane pryrodokorystuvannia: natsionalnyi i mizhnarodnyi kontekst [Balanced natural resources: national and international context]. Kyiv: Znannia. (in Ukrainian)

Vodnyi Kodeks No. 213/95-VR of June 06 (1995). [Water Code]. Ofitsinni sait Verkhovnoi Rady Ukrainy. Retrieved from: http://zakon2.rada.gov.ua/laws/show/213/95-VR (accessed 15 June 2018)

Wolf, S., Stanley, N. (2009). Wolf and Stanleyon Environmental Law: Taylor \& Francis. (in English)

Yakushenko, L. M., Yatsenko, L. D. (2015). Shchodo napriamkiv pidvyshchennia efektyvnosti vykonannia zahalnoderzhavnykh prohram u pryrodookhoronnii sferi [On the ways of increasing effectiveness of implementation of the national programs in the sphere of natural environment protection]. Informatsiino-analitychna dovidka. Retrieved from: http://www.niss.gov.ua/articles/537/ (accessed 02 December 2017)

Yatsenko, L. D. (2015). Shchodo otsinky vyklykiv natsionalnii bezpetsi v ekolohichnii sferi [On the assessment of challenges to national security in the ecological sphere]. Analitychna zapyska. Retrieved from: http://www.niss.gov.ua/ articles/1150/ (accessed 14 December 2017)

Zakon pro derzhavni tsilovi prohramy No. 1621-IV of March 18 (2004). [The Law on State Target Programs]. Ofitsiinyi sait Verkhovnoi Rady Ukrainy. Retrieved from: http://zakon2.rada.gov.ua/laws/show/1621-15 (accessed 25 May 2018)

Zakon pro pravovyi rezhym terytorii, shcho zaznala radioaktyvnoho zabrudnennia v naslidok Chornobylskoi katastrofy No. 791a-XII of February 27 (1991). [The Law on State Target Programs]. Ofitsiinyi sait Verkhovnoi Rady Ukrainy. Retrieved from: http://zakon2.rada.gov.ua/laws/show/791a-12 (accessed 25 May 2018)

Zakon pro zahalnoderzhavnu tsilovu prohramu Pytna voda Ukrainy na 2011-2020 rr. No. 3933-VI of October 20 (2011). [The Law on the legal regime of the territory that was exposed to radioactive contamination as a result of the Chernobyl disaster]. Ofitsiinyi sait Verkhovnoi Rady Ukrainy. Retrieved from: http://zakon2.rada.gov.ua/ laws/show/2455-15 (accessed 04 July 2018)

Zakon pro zahalnoderzhavnu tsilovu prohramu rozvytku vodnoho hospodarstva ta ekolohichnoho ozdorovlennia baseinu richky Dnipra na period do 2021 roku No. 4836-VI of May 24 (2012). [The Law on the national targeted program for the development of water economy and ecological rehabilitation of the Dnipro river basin in the period up till 2021]. Ofitsiinyi sait Verkhovnoi Rady Ukrainy. Retrieved from: http://zakon3.rada.gov.ua/laws/ show/4836-17 (accessed 29 November 2017)

Zarzhytskyi, O. S. (2012). Aktualni problemy pravovoho zabezpechennia ekolohichnoi polityky Ukrainy (teoretychni aspekty) [Current problems of legal support of ecological policy of Ukraine (theoretical aspects)]. Donetsk: Natsionalnyi hirnychyi universytet. (in Ukraine) 